\title{
COMMENTS
}

\section{A NEW APPROACH TO UNITED STATES ENFORCEMENT OF INTERNATIONAL ARBITRATION AWARDS}

\begin{abstract}
Pursuant to ratification of the World Bank Convention on the Settlement of Foreign Investment Disputes, the United States Congress passed the Convention on Settlement of Disputes Act of 1966, utilizing a full faith and credit approach to enforce arbitral awards rendered under the Convention. Given the likelihood of frequent requests by foreign governments for enforcement of awards against American private investors in the United States, the operation of the full faith and credit clause with respect to the enforcement of arbitration awards becomes crucial. This comment examines the issues which are presented by the congressional decision to enforce international arbitral awards through the full faith and credit clause.
\end{abstract}

$\mathrm{T}$ HE period since the close of World War II has witnessed a continuing increase in both amount and importance of foreign investment and a recognition within the United States that private foreign investment can play a significant role in this country's foreign aid program. ${ }^{1}$ One of the consequences of these developments has been a heightened concern for establishing effective means to resolve international investment disputes. ${ }^{2}$ Realization that the more traditional

\footnotetext{
1 The concern with the role of private investment in the United States' foreign aid program was voiced by President Johnson in his foreign aid message to Congress on January 14, 1965: "We are placing increasing emplasis on the role of private institutions and private enterprise in the development process, and we shall continue to do so. Foreign aid cannot succeed if we view it as a job for government alone. . . . To mobilize additional private capital, and the skills which go with it, I am asking Congress to enact an investment tax credit. I am also asking for expanded authority in connection with the investment guarantee program of the Foreign Assistance Act. However, such measures to enconrage the flow of capital to the developing world can do only a part of the job. The less developed countries must pursue policies that will create new opportunities for their own businessmen and a favorable climate for investors from abroad." H.R. Doc. No. 53, 89th Cong., 1st Sess. 6. See also Rublec, Intergovernmental Agreements Related to Foreign Private Investment, in Necotiating and Drafting International Commercial Contracts 143 (Southwestern Legal Foundaiton 1965); Tondel, Role of Private Investment in U.S. Foreign Aid, in SYmposium: Rights and Duties of Private Investors Abroad 309 (1965).

2 See generally Selected Readings on Protection by Law of Private Foricicn INvestments (Southwestern Legal Foundation 1964). See also 1.5 Proceedings of the INSTITUTE ON PRIVATE INVESTMIENTS ABRoAd (1960-64).
} 
avenues of dispute settlement $t^{3}$ have not produced satisfactory results has stimulated the investigation of new approaches, particularly the device of the multilateral convention. ${ }^{4}$ Abandoning its prior resistance to multilateral agreements dealing with protection of foreign investments, the United States on June 10, 1966, ratified the Convention on the Settlement of Foreign Investment Disputes promulgated by the International Bank for Reconstruction and Development.5 This country's participation in the agreement, known as the World Bank Convention, raises important questions with respect to

a International attempts to deal with protection of foreign investment have been both bilateral and multilateral in scope. Bilateral arrangements encompass agreements between two state parties concerning the treatment to be accorded the nationals of each within the territory of the other. See notes 9 \& 18-20 infra and accompanying text. Multilateral arrangements involve a large number of states and attempt to provide for uniform standards throughout the territories of the contracting parties of the agreement. The World Bank Convention is an illustration of the multilateral approach. See note 4 infra.

s See, e.g., OEEC Draft Convention on lnvestment Abroad, reported in $9 \mathrm{~J}$. Pub. L. 116 (1960). See also Comment on the Draft Convention by its Authors, 9 J. PuB. L. 119 (1960). Another example of the multilateral approach is seen in the International Investment Guarantee Corporation, a program under the auspices of the OECD and the World Bank. See Martin, Multilateral Investment Insurance: The OECD Proposal, 8 HARV. INT'L L. REv. 280 (1967). A final illustration of the multilateral approach is the World Bank's Convention on the Setruement of Foreign Investment Disputes. See note $\mathbf{5}$ infra. For a critical analysis of multilateral solutions to foreign investment disputes see Metzger, Multilateral Conventions for the Protection of Private Foreign Investment, 9 J. PUB. L. 133 (1960).

Current concern with foreign capital is further manifested by the post-World War II establishment of international organizations for the stimulation and protection of foreign investment. Such organizations include the International Bank for Reconstruction and Development, the International Finance Corporation, the International Development Association, the Inter-American Development Bank, the Asian Development Bank, and the Organization for Economic Cooperation and Development.

- The text of the Convention is reproduced in 4 INT'L LEgal MATERIaIs 532 (1965). For general discussions on the history and structure of the Convention see Delaume, Convention on the Settlement of Investment Disputes Between States and Nationals of Other States, 1 INT'L LAWYER 64 (1966); Farley, Commentary: The Convention on the Settlement of Investment Disputes Between States and Nationals of Other States, 5 DuQuesne L. Rev. 18 (1966); Hynning, The World Bank's Plan for the Settlement of International Investment Disputes, 51 A.B.A.J. 558 (1965); Sassoon, Convention on the Settlement of Investment Disputes, 1965 J. Bus. L. 334; Sirefman, Arbitration Under the World Bank Convention, 20 ARB. J. (n.s.) 168 (1965); Note, International Arbitration Between States and Foreign Investors-the World Bank Convention, 18 STAN. L. REv 1359 (1966).

Particular provisions of the Convention are discussed in Report of the Executive Directors of the International Bank for Reconstruction and Development on the Convention, 4 INT'L LEgal Materials 524 (1965); Broches, The Convention on the Settlement of Investment Disputes: Some Observations on Jurisdiction, 5 Colum. J. oF TransNat'L L. 263 (1966); and Schwebel \& Wetter, Arbitration and the Exhaustion of Local Remedies, 60 AMER. J. INT'L L. 484 (1966). 
the way in which obligations assumed under the Convention are to be assimilated into the federal system. A consideration of these questions is significant not only for the operation of the World Bank Convention within the United States, but also for purposes of assessing the desirability of American participation in future multilateral arrangements.

\section{United States Policy Toward Foreign Investment Disputes}

Historically, the United States has refused to join multilateral investment agreements. As recently as 1957, the State Department affirmed its opposition to multilateral agreements designed to protect foreign investment. ${ }^{\circ}$ The Department reasoned that the significance of protection achieved for investors diminished as the number of participating states increased, since compromise necessitated by conflicting interests and diverse legal systems of the parties would result in a very small area of common agreement. ${ }^{7}$ Thus, the United States took the position that it could provide better, although geographically limited, protection for its nationals by concluding bilateral arrangements on a country-by-country basis. ${ }^{8}$

Unfortunately, the bilateral treaty approach, manifested in the Treaties of Friendship, Commerce, and Navigation, ${ }^{0}$ and in the Investment Guaranty Program, ${ }^{10}$ has significant inherent limitations.

\footnotetext{
'See Hearings on Protection of Private Investments Overseas Before the Ad Foc Subcomm. of the House Comm. on Foreign Affairs, 85th Cong., 1st Sess. 14 (1957).

"According to a spokesman for the State Department, "[d]ifferences between legal systems, between national policies, and differences as to economic interests created in each case insuperable obstacles to the establishment of uniform principles . . . II I.

${ }^{8}$ Id.

' See, e.g., Treaty with Luxembourg on Friendship, Establishment, and Navigation, Feb. 23, 1962, [1963] 1 U.S.T. 250, T.I.A.S. No. 5306; Treaty with Federal Re. public of Germany on Friendship, Commerce, and Navigation, Oct. 29, 1954, [1954] 2 U.S.T. 1839, T.I.A.S. No. 3593; Treaty with Japan on Friendship, Commerce, and Navigation, Apr. 2, 1953, [1953] 2 U.S.T. 2063, T.I.A.S. No. 2863; Treaty with Greece on Friendship, Commerce, and Navigation, Aug. 3, I951, [1951] 2 U.S.T. 1829, T.I.A.S. No. 3057; Treaty with Israel on Friendship, Commerce, and Navigation, Aug, 23, 1951, [1951] 1 U.S.T. 550, T.I.A.S. No. 2948; Treaty with Ethiopia on Amity and Economic Relations, Sept. 7, 1951, [I951] 2 U.S.T. 2134, T.I.A.S. No. 2864; Treaty with Ireland on Friendship, Commerce, and Navigation, Jan. 21, 1950, [1950] 1 U.S.T. 785, T.I.A.S. No. 2155. See generally Walker, Treaties for the Encouragement and Protection of Foreign Investment: Present United States Practice, 5 AM. J. CoMp. L. 229 (1956); Walker, Modern Treaties of Friendship, Commerce and Navigation, 42 MINN. L. REv. 805 (1958).

${ }^{10}$ See Foreign Assistance Act of 1961, 22 U.S.C. $\$ \S 2181-84$ (1964); Armstrong, The United States Governiment's Investment Guaranty Program, 20 Bus. LAWYER 27 (1964); Clubb \& Vance, Incentives to Private U.S. Investment Abroad Under the For-
} 
These are illustrated by the latter which is essentially a system of insurance whereby, in exchange for a premium paid by the American investor, the United States Government guarantees his investment against specified types of losses.11 As a means for impartial settlement of investment disputes, the Program is ineffective, since its design is merely to shift the risk of loss from the investor to the United States Government rather than to provide a method by which the loss can be assessed against the responsible party. While a provision for subrogation formerly allowed the United States to place ultimate responsibility upon the proper party, ${ }^{12}$ this requirement was replaced in 1961 by vague agreements between the United States and host countries to "consult" upon the occurrence of an investment dispute.13 The bilateral nature of the Investment Guaranty Program further limits its effectiveness, since investors in countries which have not entered into an agreement with the United States cannot partake of the Program's remedy.14 In recent years, however, this objection has lost much of its force, for the number of countries which have acquiesced to the Program has increased substantially.15 While the extent to which the Program actually stimulates investment is disputed, ${ }^{16}$ it is clear that the arrangements con-

eign Assistance Program, 72 YALE L.J. 475 (1963); Miller, Protection of United States Investments Abroad: The Investment Guarantee Program of the United States Government, 32 Geo. WASF. L. REv. 288 (1963); Ray, Evolution, Scope and Utilization of Guarantees of Foreign Investment, 21 BUS. LAwYER 1051 (1966); Rivkin, Investment Guaranties and Private Investment, 19 FED. B.J. 357 (1959).

11 The specific risks covered by the Program fall into three categories: (1) inability to convert local currency into dollars, Foreign Assistance Act of 1961, §221 (b) (1) (A), 22 U.S.C. $\$ 2181$ (b) (1) (A) (1964); (2) expropriation by a foreign government, id. $\S 223$ (b), 22 U.S.C. $\S 2183$ (b) (1964); and (3) loss due to war, insurrection, or revolution, id. $\$ 221$ (b) (1) (C), 22 U.S.C. $\$ 2181$ (b) (1) (C) (1964). In 1961 Congress authorized insurance of $50-75 \%$ of an investment on an all-risk basis. See id. $\$ 221$ (b) (2), 22 U.S.C. $\$ 2181$ (b) (2) (1964); S. REP. No. 612, 87th Cong., lst Sess. 15 (1961).

13 Subrogation was an absolute requirement prior to 1961. See, e.g., Investment Guaranty Agreement with Jordan, Feb. 22, 1958, [1958] I U.S.T. 335, T.I.A.S. No. 4012.

${ }^{13}$ Exemplary of the post-1961 arrangements is the agreement with Venezuela: "The Government of the United States of America and the Government of Venezuela shall upon request of either Government consult concerning investments in Venezuela which the Government of the United States of America may guaranty." Investment Guaranty Agreement with Venezuela, Nov. 29, 1962, [1962] 1 U.S.T. 374, T.I.A.S. No. 5326.

16 See Foreign Assistance Act of 1961, \$221 (d), 22 U.S.C. \$2181 (d) (1964). Further limitations of the Program are that its provisions do not apply to investments made prior to its adoption and that new investments cannot be guaranteed for a period exceeding twenty years. See Armstrong, supra note 10, at 31-32.

${ }^{16}$ See Armstrong, supra note 10, at 32-33.

${ }^{10}$ Compare Armstrong, supra note 10, with Miller \& Christy, The United States 
tribute very little substance to the resolution of disputes arising from international capital placement.

Reflecting a more direct-though perhaps equally deficient-effort to settle investment disputes, the Treaties of Friendship, Commerce, and Navigation ${ }^{17}$ attempt to accord "national treatment"18 to the citizen and companies of either contracting party. The contracting states agree to provide the same protection for foreign investors as would be available for their own nationals, leaving resolution of disputes to the methods existing in the member states. ${ }^{10}$ The treaties also provide that questions concerning the application or interpretation of the treaties themselves may be submitted to the International Court of Justice, unless settled by other means. ${ }^{20}$

As both the Investment Guaranty Program and the Treaties of Friendship, Commerce, and Navigation demonstrate, this country has not utilized the bilateral agreement to create new procedures for settlement of investment disputes. ${ }^{21}$ Instead, the United States entre-

Government's Investment Guaranty Program: A Supplementary Report, 20 Bus. LAwYER 789 (1965).

${ }^{17}$ See note 9 supra.

18 "National treatment" has been defined in treaties as "treatment accorded within the territories of a Contracting Party upon terms no less favorable than the treatment accorded therein, in like situation, to nationals, companies, products, vessels or otlter objects, as the case may be, of such Party." Treaty with Luxembourg on Friendship, Establishment, and Navigation, Feb. 23, 1962, art. XV, para. 1, [1962] 1 U.S.T. 252, 262, T.I.A.S. No. 5306.

${ }^{19}$ The primary emphasis of the Treaties of Friendship, Commerce, and Naviga. tion is on precluding discrimination based solely on nationality. See note 18 supra and accompanying text. Barring such discrimination, the host country is free to regulate the affairs of nationals of the other contracting party in accordance with its domestic law. The manner in which the Treaties deal with enforcement of arbitration agrecments is illustrative of this limited approach. For example, Article III, paragrapli 6, of the Treaty with Luxembourg provides that: "Contracts entered into between nationals and companies of either Party and nationals and companies of the other Party, that provide for the settlement by arbitration of controversies, shall not be decmed unenforceable within the territories of such other Party merely on the grounds that the place designated for the arbitration proceedings is outside such territories or that the nationality of one or more of the arbitrators is not that of such other Party. No award duly rendered pursuant to any such contract, and final and enforceable under the laws of the place where rendered, shall be decmed invalid and denied effective means of enforcement by the authorities of either Party merely on the grounds that the place where such award was rendered is outside the territorics of such Party or that the nationality of one or more of the arbitrators is not that of such Party." Treaty with Luxembourg on Friendship, Establishment, and Navigation, Feb. 23, 1962, art. III, para. 6, [1962] 1 U.S.T. 252, 254, T.I.A.S. No. 5306.

${ }_{20}$ Treaty with Luxembourg on Friendship, Establishment, and Navigation, Feb. 23, 1962, art. XVII, para. 2, [1962] 1 U.S.T. 252, 262, T.I.A.S. No. 5306.

${ }^{21}$ See notes $15-16$ \& 19 supra and accompanying text. 
preneur has been left to the traditional remedies of local litigation or arbitration, and theoretically, international litigation..22 This latter avenue is of little practical importance because the rules of international litigation permit only nation-states to present claims. Thus, the United States Government must espouse the claim of the American investor in international litigation. Because the Government does not favor this mode of settlement, ${ }^{23}$ it is resorted to only infrequently. As an alternative, the American entrepreneur must seek redress by local litigation either in a forum of the host country or in American courts. However, in addition to expense and confusing differences in foreign legal systems, ${ }^{24}$ it may be expected that, in proceeding against the sovereign in the courts or administrative bodies of the host country, remedies will be less than satisfactory, since such institutions probably will not grant relief contrary to the interests of their own government. ${ }^{25}$ Indeed, it may be that local remedies against the sovereign are nonexistent. ${ }^{26}$

While suits in American courts will not be subject to the limitations found in foreign tribunals, an American investor may experience the same unsatisfactory result. Though problems of foreign law and inherent bias of the judiciary are unlikely to arise, the investor will undoubtedly confront the defenses of sovereign immunity from jurisdiction ${ }^{27}$ and sovereign immunity from execution, ${ }^{28}$ which

\footnotetext{
25 See generally Young, Remedies of Private Claimants Against Foreign States, in Selected Readings on Protection by Law of Private Foreign Investments 905 (Southwestern Legal Foundation 1964).

${ }^{23}$ See Wetter, Diplomatic Assistance to Private Investment: A Study of the Theory and Practice of the United States During the Twentieth Century, 29 U. GH. L. REv. 275 (1962); Young, supra note 22, at 919-26. In analyzing the State Department's attitude toward official espousal of claims, a leading commentator has noted that "it has been jokingly said that when relations with a foreign state are good, the department is reluctant to press an unpleasant claim for fear of spoiling them; while if relations are bad, it is reluctant to spend time and effort on a futile mission." Id. at 919-20.

${ }^{24}$ See generally Domke, The American Trader in Foreign Litigation, in 2 Dorng Bus. Abroad 357 (Landau ed. 1962); Hess, Litigation and Arbitration in International Trade, 22 J. Mo. BAR 256 (1966).

${ }^{25}$ See Lillich, The Effectiveness of the Local Remedies Rule Today, 58 Proc. AM. Soc'Y INT'L L. 101 (1964); Mummery, Increasing the Use of Local Remedies, 58 Proc. AMr. Soc'y INT'L L. 107 (1964).

${ }^{20}$ See Verdross, The Status of Foreign Private Interests Stemming from Economic Development Agreements with Arbitration Clauses, in SELEcted Readings on ProtecTION by LAw of Private Foreign INVEstments 117, 133-34 (Southwestern Legal Foundation 1964).

${ }^{27}$ In the Tate Letter, 26 STATE Dep'T. Bull. 984 (1952), the State Department announced its acceptance of the restrictive theory of immunity of foreign sovereigns from jurisdiction. Thus, the Department would suggest immunity if the suit arose out of acts
} 
may bar recovery. In addition, the "Act of State" doctrine may preclude judicial inquiry into the controversy between the parties.20 Often the publicity attendant upon litigation produces a hardening of lines of conflict, thus rendering an amicable settlement more difficult. This last factor would seem to have particular significance when one of the parties to the litigation is a sovereign state, since investment disputes traditionally have political overtones. Therefore, on balance, private litigation has not proved an acceptable solution to the resolution of investment disputes.

A final avenue for settling an investment dispute would involve its submission to international commercial arbitration. ${ }^{30}$ This pro-

of a purely governmental nature (jure imperii); however, such a suggestion would not be filed if the suit were based on commercial acts (jure gestionis). Victory Transp. Inc. v. Comisaria General, 336 F.2d 354, 360 (2d Cir. 1964), cert. denied, 381 U.S. 934 (1965), offered what is to date the clearest definition of acts jure imperii: "Sucli acts jure imperii are generally limited to the following categories:

(1) internal administrative acts, such as expulsion of an alien.

(2) legislative acts, such as nationalization.

(3) acts concerning the armed forces.

(4) acts concerning diplomatic activity.

(5) public loans."

Under present practice, domestic courts are bound by the State Department's sug. gestion of immunity. See note 67 infra and accompanying text. See generally R. FalK, The Role of Domestic Courts in the International Legat Order 139-70 (1964); Comment, The Jurisdictional Immunity of Foreign Sovereigns, 63 YALE L.J. 1148 (1954).

${ }^{28}$ Until the promulgation of the "restrictive" theory of sovereign immunity by the Tate Letter, supra note 27 , the doctrine of immunity from execution was gencrally subsumed under the immunity from jurisdiction question. If immunity from jurisdiction were found, immunity from execution followed a fortiori. See Griffin, Execution Against the Foreign Sovereign's Property: The Current Scene, 55 Proc. AM. Soc'Y INT'L L. 105, 107 (1961). In cases where jurisdiction is found to be valid under the "restrictive" theory, immunity from execution remains in force. It has been suggested that the tenacity of the immunity from execution doctrine is traceable to the belief that "execution against state property [is] an offense against the dignity of the state to a far greater degree than submission to jurisdiction. There is more likely to be bad feeling and friction resulting from such seizures, which are likely to interfere with functions of the state." Id. at 113. See generally Cohen, Some Problems of Doing Business with State Trading Agencies, 1965 Ird. L.F. 520, 535.38.

${ }^{29}$ The United States Supreme Court held in Banco Nacional de Cuba v. Sabbatino, 376 U.S. 398, 401 (1964), that the "Act of State" doctrine "precludes the courts of this country from inquiring into the validity of the public acts of a recognized forcign sovereign power committed within its own territory." Subsequently, Congress partially nullified the Court's holding by enacting the Sabbatino or Hickenlopper Amendment to the Foreign Assistance Act. See Foreign Assistance Act of 1962, $\S 301$ (d) (4), 22 U.S.C. $\$ 2370$ (e) (2) (Supp. I, 1965). The amendment was upheld in Banco Nacional de Cuba v. Farr, 243 F. Supp. 957 (S.D.N.Y. 1965).

${ }^{\text {so }}$ See generally Bourquin, Arbitration and Economic Development Agreements, 15 Bus. LAWYER 860 (1960); Verdross, supra note 26. 
cedure, obtained through either prior agreement or an ad hoc consent to arbitration, requires careful attention to the drafting of the submission agreement, since the parties must agree on appointment of arbitrators, the location of the proceedings, and relevant procedural details. ${ }^{31}$ While the successful arbitration of the conflict between the Arabian American Oil Company and the government of Saudi Arabia illustrates the possibilities of international arbitration, ${ }^{32}$ the absence of effective machinery for enforcement of awards renders the ultimate benefits of settlement dependent exclusively on the voluntary compliance of the state party. ${ }^{33}$

\section{The Operation of the World Bank Convention}

The World Bank Convention seeks to make resort to the remedy of international arbitration more attractive by placing the more important features of arbitration on a permanent, institutional basis, especially in the area of enforcement of awards. ${ }^{34}$ In pursuit of this end, the Convention established at the Washington, D.C., headquarters of the World Bank a centre to be operated by a SecretaryGeneral $^{35}$ and an Administrative Council. ${ }^{36}$ Furthermore, in institutionalizing the essentials of international arbitration, the Convention has three noteworthy features: (1) it creates a forum in which a private investor may confront a state party; (2) it establishes procedures for enforcement of awards; and (3) it embodies within its articles a number of "neutral" solutions which specify the procedural details of arbitration, should the parties fail to do so. However, the Convention merely provides a forum and does not require compulsory arbitration. ${ }^{37}$ Indeed, ratification of the Convention does not obligate a state to submit disputes to the centre.

\footnotetext{
${ }^{31}$ See Bourquin, supra note 30 , at 862 .

as See the discussion of the Arabian oil case in Ray, Law Governing Contracts Between States and Foreign Nationals, in ProceEdrNGS OF THE 1960 INSTrTUTE oN PrIVATE INVESTMENTS ABroAd 492 (Southwestern Legal Foundation 1964).

${ }^{33}$ See generally Haight, American Foreign Trade and Investment Disputes, 14 ARB. J. (n.s.) 73 (1959); Schachter, The Enforcement of International Judicial and Arbitral Decisions, 54 AM. J. INT'L L. 1 (1960); Schachter, Private Foreign Investment and International Organization, 45 CORNELL L.Q. 415 (1960). See also Dispute-Settling and Avoidance Mechanisms for Foreign Trade Controversies, ProJECT 104 OF THE WORLD Rule of LAw CENTER, Duke University School of Law.

34 See note 33 supra and accompanying text.

${ }^{30}$ Articles 2, 9-11.

36 Articles 4-8.

${ }^{37}$ The concern for equal treatment of foreign investors and nationals formed the
} 
The arbitration processes of the centre are available for the resolution of any dispute in which the subject matter and personal jurisdictional requisites of the Convention can be met. The centre's jurisdiction over the parties, based exclusively on their written consent, ${ }^{38}$ can be achieved by at least three methods: ${ }^{30}$ (1) a compromis or ad hoc consent which would be given after the dispute has arisen; (2) a provision in an investment concession agreement obligating the parties to submit future disputes to the centre's tribunals; and (3) an offer by a state in its investment legislation-to be accepted by the investor in writing-to submit disputes to the centre. ${ }^{40}$ From an in-

basis of objections to the World Bank Convention by the states of Central and South America. A spokesman for those countries advanced three reasons for the unacceptability of the Convention. First, there was no need for the Convention in Latin America since local courts accord foreign investors the same rights as nationals. Second, the Convention affords a foreign national-solely because he is a foreigner-the right to sue a sovereign state outside its territory, thus avoiding local courts. Finally, nationals are placed in an inferior position vis-a-vis foreign investors. Press Release No. 57, Sept. 9, 1964, reprinted in 3 INT'c Legal MATERIALS 1174-75 (1964) (statement by the Hon. Felix Ruiz, Vice-President, Banco Central de Chile and Chilean Representative to the World Bank).

${ }^{3 s}$ Article 25 sets forth the jurisdictional requirements of the centre: "(1) The jurisdiction of the Centre shall extend to any legal dispute arising directly out of an investment, between a Contracting State (or any constituent subdivision or agency of a Contracting State designated to the Centre by that State) and a national of another Contracting State, which the partics to the dispute consent in writing to submit to the Centre. When the parties have given their consent, no party may withdraw its consent unilaterally. (2) 'National of another Contracting State' means: (a) any natural person who had the nationality of a Contracting State other than the State party to the dispute on the date on which the parties consented to submit such dispute to conciliation or arbitration as well as on the date on which the request was registered ... but does not include any person who on either date also had the nationality of the Contracting State party to the dispute; and (b) any juridical person which had the nationality of a Contracting State other than the State party to the dispute on the date on which the parties consented to submit such dispute to conciliation or arbitration and any juridical person which had the nationality of the Contracting Statc party to tbe dispute on that date and which, because of foreign control, the parties lave agreed should be treated as a national of another Contracting State for the purposes of this Convention. (3) Consent by a constituent subdivision or agency of a Contracting State shall require the approval of that State unless that State notifies the Centre that no such approval is required. (4) Any Contracting State may, at the time of ratification, acceptance or approval of this Convention or at any time thereafter, notify the Centre of the class or classes or disputes which it would or would not consider submitting to the jurisdiction of the Centre. ... Such notification shall not constitute the consent required by paragraph (1)."

${ }^{30}$ See Report of the Executive Directors, supra note 5, at 527. The first consent agreement to be made public is article 50 of the Convention of Establishment and Implementation between Mauritania and Société des Mines de Mauritania, July 19, 1967, reprinted in 6 INT'L LEGAL MATERIALS 1085 (1967).

10 See id. According consent through legislation raises several questions which are as of yet unanswered. For example, could the mere act of investing pursuant to lcgis- 
vestor's point of view, a provision in the concession agreement covering future disputes would be the preferable means of giving consent, since the political nature of some disputes might effectively preclude a government's granting an ad hoc consent. In addition to consent, there are subject-matter jurisdictional requirements relating to the identity of the parties and to the nature of their dispute. First, the dispute must be one between a contracting state and a national of another state. ${ }^{41}$ This condition serves to prevent the centre from assuming jurisdiction over a dispute betwèn a state and one of its own nationals, and it seems clear that strict compliance with this requirement will be necessary in order to invoke the centre's jurisdiction. ${ }^{42}$ Secondly, the Convention requires that a dispute be "of a legal nature arising directly out of an investment." 43 The substantive nature of this latter requirement is unclear; ${ }^{44}$ indeed the

lation containing an offer of consent to arbitration be deemed acceptance of that offer? Could a state withdraw its offer of consent prior to acceptance by an investor? The specific language of the legislation will be of crucial importance, though in any event, questions of timing and unilateral withdrawal of consent may still be anticipated. See Broches, supra note 5, at 268-70.

1 See note 39 supra.

'See note 38 supra for the definition of "national of another contracting state" contained in article 25.

(3) The Convention does not govern disputes between two natural or juridical persons who are nationals of different states, the usual parties to an international trade dispute. See article 25. However, there is a possible area of overlap between trade and investment disputes-between a private party national of state $A$ and a state trading corporation of state B. In such cases it is possible that the absence of a definition of "investment" in the Convention, see note 45 infra and accompanying text, would permit the parties to consent to the submission of a trade dispute to the centre, see S. ExEc. REP. No. 2, 89th Cong., 2d Sess. 15 (1966). While it is possible that the SecretaryGencral would declare such a dispute to be outside the scope of the Convention, see article 11, the more probable result would be that the Secretary-General would register the application to the centre and leave the question of jurisdiction to the arbitral tribunal under article 41 .

It is clear that the provisions of the Convention do not extend to disputes between two states. See article 25. Consideration was given to extending the coverage of the Convention to disputes in which a state was subrogated to the claim of a private investor. Due to opposition from developing nations, however, the proposal was omitted from the final draft of the Convention. See Broches, supra note 5, at 267; Broches, Development of International Law by the International Bank for Reconstruction and Development, 59 Proc. AMER. Soc'y INT'L L. 33, 37 (1965).

"The Report of the Executive Directors states that the term "legal dispute" is a reflection of the intention that jurisdiction of the centre extend to conflicts of right, but not to conflicts of interest. Report of Executive Directors, supra note 5, at 528. The distinction is not particularly illuminating and has been criticized by at least one commentator. See Sirefman, supra note 5, at 174. A more helpful statement in the directors' report is that "[t]he dispute must concern the existence or scope of a legal right or obligation, or the nature or extent of the reparation to be made for breach of 
report of the executive directors suggests that the absence of a detailed elaboration of the scope of this requisite was intended by the draftsmen of the Convention in order to give the Convention the desired flexibility. ${ }^{45}$ In fact, some commentators have anticipated that, barring an exceptional case, the parties will be left free to determine for themselves-by act of written consent-that their dispute is of a legal nature arising directly out of an investment. ${ }^{40}$

Although not traditional jurisdictional rules, two additional provisions of the Convention bear directly on submission of disputes to the centre. First, allowing a state to present to the SecretaryGeneral a classification of disputes which the sovereign would not consider submitting to the centre ${ }^{47}$ dispels any fears that ratification of the Convention involved compulsory arbitration. Moreover, the provision permits a state to withhold from a public forum particularly sensitive issues such as questions affecting its national security. The second provision, allowing a precondition of exhaustion of local remedies, is encompassed in article 26:

Consent of the Parties to arbitration under this Convention shall, unless otherwise stated, be deemed consent to such arbitration to the exclusion of any other remedy. A Contracting State may require the exhaustion of local administrative or judicial remedies as a condition of its consent to arbitration under this Convention.

Aside from serious problems associated with local remedies, ${ }^{48}$ the exhaustion requirement may render the task of the arbitral tribunal more difficult because its deliberations may be substantially removed in time from the events which gave rise to the disputes. Unfortunately, it appears that many underdeveloped countries will insist on exhaustion of local remedies as a prerequisite to arbitration, apparently presuming that foreign investors are thereby in an equal

a legal obligation." Report of the Executive Directors, supra note 5, at 528. In this regard, it is important to note that the parties may agree on a hody of law to govern the dispute and the jurisdictional requirement of "Iegal dispute" must be read in this context. See notes 59-60 infra and accompanying text.

${ }^{25}$ 'No attempt was made to define the term 'investment' given the essential requircment of consent by the parties, and the mechanism through which Contracting States can make known in advance, if they so desire, the classes of disputes which they would or would not consider submitting to the Centre ...." Report of the Executive Directors, supra note 5 , at 528 .

${ }^{40}$ See Broches, The Convention on the Settlement of Investment Disputes: Some Observations on Jurisdiction, 5 Colum. J. OF Transnat'L L. 263, 268 (1966).

${ }^{47}$ See note 38 supra and accompanying text.

${ }^{48}$ See notes 24-26 supra and accompanying text. 
position with nationals of the host country. ${ }^{49}$ Nevertheless, competition for capital may cause states to delete exhaustion requirements in order to offer an attractive climate for scarce foreign investment.

Once the centre has assumed jurisdiction and the arbitral tribunal has rendered a decision, ${ }^{50}$ the Convention's enforcement machinery is available to the successful party. The central provision dealing with enforcement of awards-the only significant obligation which a contracting party must assume by ratifying the Convention -is article 54, which provides in part:

(1) Each contracting state shall recognize an award rendered pursuant to this Convention as binding and enforce the pecuniary obligations imposed by that award within its territories as if it were a final judgment of a court in that state. A contracting state with a federal constitution may enforce such an award in or through its federal courts and may provide that such courts shall treat the award as if it were a final judgment of the courts of a constituent state.

- ...

(3) Execution of the award shall be governed by the laws concerning the execution of judgments in force in the state in whose territories such execution is sought. ${ }^{51}$

The Convention also includes provisions for revision, ${ }^{52}$ interpretation, ${ }^{53}$ and annulment ${ }^{54}$ of awards. Therefore, enforcement of awards

\footnotetext{
${ }^{10}$ See note 37 supra. See also Note, 18 Stan. L. REv. 1359, 1377 (1966). The General Counsel of the World Bank, responding to the objections by the Latin American States, pointed out that the Convention does not require compulsory arbitration, and thus a contracting party is not required to submit disputes to the centre. In addition, it was emphasized that the Convention does not provide rights for aliens which are unavailable to nationals, since article 26 of the Convention permits a state to require exhaustion of local remedies.

so The powers and functions of the Arbitral Tribunals are set forth in articles 41 49 of the Convention, and the contents of those provisions are generally self-explanatory. It should be noted that the Convention affords the parties to the dispute a high degree of control of the details of arbitration. See notes 58-64 infra. Upon the rendition of an award, the Secretary-General is vested with the power to authenticate the award and issue certified copies of the award. See article 49.

"See note 28 supra and accompanying text; note 98 infra and accompanying text.

52 Article 51: “(1) Either party may request revision of the award by an application in writing addressed to the Secretary-General on the ground of discovery of some fact of such a nature as decisively to affect the award, provided that when the award was rendered that fact was unknown to the Tribunal and to the applicant and that the applicant's ignorance of that fact was not due to negligence."

63 Article 50: "(1) If any dispute shall arise between the parties as to the meaning or scope of an award, either party may request interpretation of the award by an application in writing addressed to the Secretary-General."

"Article 52: "(1) Either party may request annulment of the award by an applica-
} 
under article 54 is the only remedy which may be sought in the courts of contracting states. ${ }^{55}$ The party seeking enforcement will have a large number of potential forums available, since each contracting state is required to enforce the award against any agent or property of the losing party within its territorial limits, even though neither the enforcing state nor one of its nationals was a party to the dispute. ${ }^{56}$ Yet, the Convention allows the contracting states to retain considerable flexibility in opposing award enforcement, for execution of awards is subject to the rules of domestic law in the enforcing jurisdictions. The unfortunate result for the investor in states having the sovereign immunity defense is that enforcement against a state party may be an illusion. ${ }^{57}$

Finally, the Convention contains a number of "neutral" provisions designed to supply the procedural details of arbitration should the parties neglect or fail to agree on these matters. ${ }^{58}$ This type of provision is illustrated by article $42(1)$ of the Convention which deals with the law to be applied by the arbitral tribunals: ${ }^{50}$

The Tribunal shall decide a dispute in accordance with such rules of law as may be agreed by the parties. In the absence of such agreement, the Tribunal shall apply the law of the Contracting State party to the dispute (including its rules on the conflict of laws) and such rules of international law as may be applicable. 00

tion in writing addressed to the Secretary-General on one or more of the following grounds: (a) that the tribunal was not properly constituted; (b) that the tribunal has manifestly exceeded its powers; (c) that there was corruption on a part of a mem. ber of the Tribunal; (d) that there has been a serious departure from a fundamental rule of procedure; or (e) that the award has failed to state the reasons on which it is based."

Ev Limiting the action to enforcement only is important because of the existence of laws in the contracting state which pertain to modification of arbitral awards. See, e.g., United States Arbitration Act $\$ \S 10-11,9$ U.S.C. $\$ \S 10-11$ (1964). Thus, the Convention on the Settlement of Disputes Act expressly excludes the application of the Arbitration Act in actions upon Convention awards. See S. REP. No. 1374, 89th Cong., $2 d$ Sess. 2 (1966); note 74 infra.

"See note 37 supra and accompanying text.

${ }^{6}$ See note 28 supra; note 98 infra.

${ }^{68}$ Although the Convention does not expressly contain any information as to whether parties may agree on certain procedures after they have consented to submit a dispute to the centre, there would seem to be no objections to such an agreement. See International Convention for Settlement of Investment Disputes: Provisional Regulations and Rules, ch. 1, art. 17, in 6 Int'l Legal Materials 225, 267 (1967).

"The providing of neutral provisions or "stop-gap" law is a common drafting technique in the major European civil codes. See generally M. RHEINSTEIN, CAsES ON DECEDENTs' Estates 472 (2d ed. 1955).

co "International law" is understood by reference to article $38(1)$ of the Statute of 
The Convention also includes "neutral" provisions relating to appointment of arbitrators, ${ }^{61}$ production of documents, ${ }^{62}$ and the arbitration rules to be applied. ${ }^{63}$ The existence of such provisions should remove the possibility of impasse over the details of arbitration, a danger which has severely restricted the successful use of ad hoc resolutions in the past. ${ }^{44}$

\section{Significance of American Participation in the WORLD BANK Gonvention}

While response to the Gonvention from the membership of the World Bank has been encouraging, ${ }^{65}$ there have been voices of dis-

the International Court of Justice, allowance being made for the fact that article 38 was designed to apply to inter-state disputes. Report of the Executive Directors of the World Bank on the Convention, 4 INT'L Leal MATERIALs 524, 530 (1965). Article 38 (1) of the Statute of the International Court of Justice provides that: "(1) The Court, whose function it is to decide in accordance with international law such disputes as are submitted to it, shall apply: a. international conventions, whether general or particular, establishing rules expressly recognized by the contesting states; $b$. international custom, as evidence of a general practice accepted as law; $c$. the general principles of law recognized by civilized nations; d. subject to the provisions of Article 59 , judicial decisions and the teachings of the most highly qualified publicists of the various nations, as subsidiary means for the determination of rules of law." Perhaps using article $38(I)$ the Convention tribunals will develop a significant body of new public international law. See S. Exec. REP. No. 2, 89th Cong., 2d Sess. I9 (I966).

o1 See article 38.

02 Article 43: "Except as the parties otherwise agree, the Tribunal may, if it deems it necessary at any stage of the proceedings, (a) call upon the parties to produce documents or other evidence, and (b) visit the scene connected with the dispute, and conduct such inquiries there as it may deem appropriate."

${ }^{03}$ Article 44.

os See text accompanying note 3 I supra.

of Participation in the Convention is not restricted to the membership of the World Bank; thus, the Communist Bloc nations could adhere to its provisions. However, such a prospect appears unlikely in the near future. See Hynning, The World Bank's Plan for the Settlement of International Investment Disputes, 51 A.B.A.J. 558, 559 (1965). The states which have signed the Convention as of October 26, 1966, are as follows (in the order of signing): Tunisia, United Kingdom, Jamaica, Ivory Coast, Pakistan, Nigeria, Mauritania, Niger, Central African Republic, United States, Liberia, Dahomey, Upper Volta, Ethiopia, Gabon, Cameroon, Japan, Sweden, Somalia, Sierra Leone, Nepal, Luxembourg, Denmark, Morocco, Malaysia, Italy, Ghana, Belgium, France, Congo (Brazzavilie), Republic of China, Togo, Germany, Cyprus, Greece, Repubhic of Korea, Chad, Austria, Kenya, Netherlands, Malagasy Republic, Uganda, Malawi, Norway, Iceland, Ireland, Senegal, Afghanistan, Trinidad, and Tobago. Of the signatories, the following have ratified the Convention: Nigeria, Mauritania, Ivory Coast, Central African Republic, Gabon, Uganda, United States, Tunisia, Congo (Brazzaville), Ghana, Iceland, Sierra Leone, Malaysia, Malawi, Chad, Upper Volta, Dahomey, Malagasy Republic, Jamaica, Netherlands, and Pakistan. For states ratifying the Convention after September 14, 1966, the Convention will enter into force thirty days after the deposit of the ratification instruments. See Broches, The Convention 
approval from certain quarters, notably the states of Latin America.0 On balance, sponsorship of the Convention by the World Bank may be the greatest reason for optimism concerning successful operation of the Convention, both because of the prestige of the Bank as an institution and because international investment disputes are often accompanied by the need for refinancing. ${ }^{07}$

Though United States ratification might lead to the expectation that the Convention will establish itself as a viable alternative to current confusion, this country faces only minimal involvement in the operation of the Convention, since it receives foreign capital in relatively small amounts. Thus, the United States is not likely to be a party to an investment dispute presented to the centre. Moreover, foreign investment in the United States does not occur pursuant to a concession agreement, and therefore, like domestic investment, is subject to applicable state and federal regulation. Continuation of this policy means that the United States will never enter into agreements calling for submission of future disputes to arbitration..$^{08}$ The probable limited participation of the United States was confirmed by advocates of the Convention who, in response to congressional fears that questions of federal regulatory law would be submitted for determination by an arbitral tribunal, ${ }^{00}$ pointed out that this Government will accord its consent to arbitration only on an ad hoc basis, and only when no federal law issues are involved.70 In fact, the Convention's provision permitting a state to restrict the disputes it is willing to submit to the Convention ${ }^{71}$ may constitute

and the Settlement of Investment Disputes: Some Observations on Jurisdiction, 5 Cotum. J. OF TRANSNAT't L. 263,264 n.4 (1966).

${ }^{\mathrm{B}}$ See note 37 supra.

er See Hynning, supra note 65, at 559 n.11, citing The Suez Canal SETTLement 3 (Lauterpacht ed. 1961). It is hoped by some that states will be attracted to the Convention as a means for strengthening their credit status and thereby increasing the influx of foreign capital within their borders. Hynning, supra note 65, at 559.

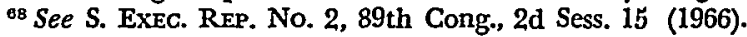

${ }^{8}$ This congressional fear was the source of considerable concern in the Senate Foreign Relations Committee Hearings on the Convention. See id. at 10.

${ }^{70}$ Letter of Apr. 7, 1966, from M.F. Cohen, Chairman of the Securities and Excliange Commission, to Senator Fulbright, S. ExEc. REP. No. 2, 89th Cong., 2d Sess. 11 (1966). A state could permanently withdraw particular conflicts from the Convention's consideration by filing with the centre, pursuant to article 25, a list of classes of disputes which the state will not submit to arbitration. The United States, following its policy of according consent only on an ad hoc basis, does not plan to submit such a list. S. ExEc. Rep. No. 2, 89th Cong., 2d Sess. 15 (1966).

${ }^{71}$ Report of the Executive Directors, supra note 59, at 527; notes 38.41 supra. 
the major reason underlying this nation's ratification of the Convention.

The requirement that any contracting state must enforce Convention awards in or through its courts presents entirely different problems for this country. ${ }^{72}$ Since many foreign states and investors -both American and foreign-own assets within the United States, American courts will be directly involved. The drafters of the Convention recognized that contracting states having federal systems faced special problems in enforcing awards. Thus, they recommended that such states enforce Convention awards through their federal courts as though the awards were a judgment of a constituent state of the federation. ${ }^{73}$ The United States Congress accepted this suggestion in its entirety in passing the Convention on the Settlement of Investment Disputes Act of $1966 .^{74}$ The Act gave original jurisdiction over enforcement of Convention awards to federal district courts, which are to assume jurisdiction without regard to amount in controversy. ${ }^{75}$ Furthermore, it provided that:

the pecuniary obligations imposed by such an award shall be enforced and shall be given the same full faith and credit as if the award were a final judgment of a court of general jurisdiction of one of the several States. ${ }^{76}$

The legislative history of the Act indicates that the draftsmen considered the full faith and credit procedure to be a relatively uncomplicated means for enforcement. ${ }^{77}$ Unfortunately, the presumed

${ }^{72}$ See note 51 supra and accompanying text.

${ }^{73} I d$.

" 22 U.S.C. $\$ \S 1650-1650 a$ (Supp. II, 1965-66). Section 1650: "The President may make such appointments of representatives and panel members as may be provided for under the convention." Section 1650a: "(a) An award of an arbitral tribunal rendered pursuant to chapter IV of the convention shall create a right arising under a treaty of the United States. The pecuniary obligations imposed by such an award shall be enforced and shall be given the same full faith and credit as if the award were a final judgment of a court of general jurisdiction of one of the several States. The Federal Arbitration Act (9 U.S.C. $\$ 1$ et seq.) shall not apply to enforcement of awards rendered pursuant to the convention. (b) The district courts of the United States (including the courts enumerated in title 28, United States Code, section 460) shall have exclusive jurisdiction over actions and proceedings under paragraph (a) of this section, regardless of the amount in controversy." See S. REP. No. 1374, 89th Cong., 2d Sess. (1966); H.R. REP. No. 1741, 89th Cong., 2d Sess. (1966).

75 Convention on the Settlement of Investment Disputes Act $\$ 3(\mathrm{~b}), 22$ U.S.C. $\S 1650 \mathrm{a}$ (b) (Supp. II, 1965-66).

${ }^{70} I d . \$ 3(\mathrm{a}), 22$ U.S.C. $\$ 1650 \mathrm{a}$ (a) (Supp. II, 1965-66).

"7 See S. ReP. No. 1374, 89th Cong., 2d Sess. 3-4 (1966) (statement by Fred B. Smith, General Counsel, Department of the Treasury). 
simplicity of the full faith and credit doctrine is not realized upon its application to the Convention. ${ }^{78}$

It is well settled that federal courts must give full faith and credit to state court judgments. ${ }^{79}$ However, in contrast to federal court enforcement of a judgment of another federal court, ${ }^{80}$ there is no summary enforcement procedure applicable to state court judgments sought to be enforced in federal courts. ${ }^{81}$ A party seeking implementation of a state court judgment, and therefore also a Convention award, must institute an original action on the award and obtain a new judgment in the federal court, ${ }^{82}$ with the result that docket delay and dilatory tactics will be available to parties resisting enforcement. These obstacles are particularly objectionable since they could have been easily avoided by treating Convention awards as final judgments of federal courts in order to obtain the advantages of the Registration of Judgments Act ${ }^{83}$ available for federal court

\footnotetext{
${ }^{78}$ See generally Childs, Full Faith and Credit: The Lawyer's Clause, $36 \mathrm{KY}$. L.J. 30 (1947); Corwin, The "Full Faith and Credit" Clause, 81 U. PA. L. REv. 371 (1933); Nadelmann, Full Faith and Credit to Judgments and Public Acts, 56 MicH. L. REv. 33 (1957); Ross, "Full Faith and Credit" in a Federal System, 20 MinN. L. REv. 140 (1936); Sumner, Full Faith and Credit for Judicial Proceedings, 2 U.C.L.A.L. REv. 441 (1955).

${ }^{79}$ The specific terms of the Constitution require only that state courts must give full faith and credit to the public acts, records, and judicial proceedings of sister states. U.S. CoNST. art. IV, $\$ 1$. However, Congress has extended the application of the doctrine to "every court within the United States and its Territories and Posses. sions . . ." Act of June 25, 1948, $\S 1738,28$ U.S.C. $\$ 1738$ (1964). This has been interpreted to require federal courts to give full faith and credit to the judgments of state courts. See, e.g., Huron Holding Corp. v. Lincoln Mine Operating Co., 312 U.S. 183, 193 (1941); Davis v. Davis, 305 U.S. 32, 34 (1938).

${ }^{80}$ See Act of June 25, 1948, $\S 12$ (o), 28 U.S.C. $\$ 1963$ (1964). A party secking cnforcement in a federal district court of a judgment rendered by another federal district court must first file a certified copy of the judgment with the court in which enforcement is sought. The judgment is then registered in the records of the enforcing court as though it were rendered by it. Having registered a judgment, the plaintiff is then entitled to seek enforcement through execution or garnishment. See Note, Registration of Federal Judgments, 42 Iown L. Rev. 285 (1957).

${ }^{81}$ The Uniform Enforcement of Foreign Judgments Act, which applics only in state courts, has been adopted by nine states. See Lefiar, The New Uniform Foreign Judgments Act, 24 N.Y.U.L.Q. 336 (1949). The Federal Registration of Judgments Act applies only to federal court judgments in federal courts. See Act of Junc 25, 1948, $\S 12$ (o), 28 U.S.C. $\$ 1963$ (1964); Note, Registration of Federal Judgments, 42 Iows L. REv. 285 (1957).

${ }^{83}$ The state party seeking enforcement of the award may confront special prob. lems where the defendant is insolvent at the time of the proceeding, since the forcign judgment may not have priority over contract debts in the distribution of assets. See, e.g., Beilman v. Poe, 138 Md. 482, 114 A. 568 (1921).

${ }^{83}$ See Act of June $25,1948, \S 12$ (o), 28 U.S.C. $\$ 1963$ (1964); Note, Registration of Federal Judgments, 42 IowA L. REv. 285 (1957).
} 
decrees. As a consequence of this failure to provide a summary procedure, the party seeking enforcement of the Convention award must file a complaint on the award, obtain jurisdiction pursuant to rule 4 of the Federal Rules of Civil Procedure, and comply with the venue provisions of sections 1391 and 1392 of title 28 of the United States Code. ${ }^{84}$

After an enforcement suit has been properly instituted, the federal district court must then consider questions directly relating to the full faith and credit clause upon which the enforcement procedure of the Act is based. Under current full faith and credit practice-at least with respect to judgments for money damages-the enforcing forum must enforce a valid final judgment of a sister state.85 While the Convention on the Settlement of Disputes Act obviates several problems by expressly attributing judgment status and finality to Convention awards, ${ }^{86}$ and limits the enforcing court's obligation to the enforcement of "pecuniary damages," 87 the Act does not deal with the question of the validity of Convention awards. Therefore, in obedience to established precedent, a federal court must review an award by reference to the law of the rendering forum. Since the rendering forum of Convention awards is an arbitral tribunal, the provisions of the World Bank Convention presumably serve as the law which determines the validity of these awards.

Judgments traditionally entitled to full faith and credit must possess a composite of factors relating to the power of the forum to affect the relations of the parties before it. The determination of a judgment's validity necessitates a three-step inquiry. First, the enforcing court must find that the rendering forum had jurisdiction, both of the person and of the subject matter. Secondly, the law of the rendering forum must not permit the alleged defect to be raised

\footnotetext{
${ }^{86}$ The choice of a specific district court in which to institute an enforcement action depends upon the law and rules of venue, see Act of June 25, 1948, $\$ \S 1391-92,28$ U.S.C. $\$ \S 1391-92$ (1964), and service of process, see FED. R. Civ. P. 4. Jurisdiction over a foreign sovereign may frequently be obtained by attachment of property owned by the sovereign since personal service is often unavailable. See FED. R. Grv. P. 4 (e); Elliot \&. Green, Quasi in Rem Jurisdiction in Federal Courts, 48 lowA L. Rev. 300 (1963); cf. Victory Transp., Inc. v. Comisaria General, 336 F.2d 354, 363 (2d Cir. 1964), cert. denied, 381 U.S. 934 (1965).

${ }^{85}$ See Fauntleroy v. Lum, 210 U.S. 230 (1908); Christmas v. Russell, 72 U.S. (5 Wall.) 290 (1866); Restatement of Conflict of LAws $\$ 450$ (1934).

${ }^{80}$ See note 74 supra.

${ }^{87}$ Id.
} 
collaterally. Finally, the rendition of the judgment must not have deprived a party of the protections of due process of law. ${ }^{88}$ If such conclusions are reached on all three inquiries, the judgment is deemed valid and therefore entitled to full faith and credit.

The law of the rendering forum in international arbitrationthe Convention itself-apparently does not contemplate collateral attack on awards. This conclusion is buttressed by several Convention provisions. First, the Convention permits either party to raise the jurisdictional issue at the arbitration proceedings. ${ }^{80}$ It is reasonable to assume that the draftsmen, having in mind speedy enforcement of the award, intended the meeting as the sole occasion for raising the jurisdictional point. Secondly, a form of direct appeal is available through the Convention's own procedures for revision, ${ }^{00}$ interpretation, ${ }^{91}$ and annulment of awards. ${ }^{92}$ Finally, the Convention's most persuasive support for the impenetrability of its awards

\footnotetext{
${ }^{88} \mathrm{It}$ is well settled under the full faith and credit clause that the validity of a judgment is determined by reference to the law of the rendering forum. See, e.g., Fauntleroy v. Lum, 210 U.S. 230 (1908). The content of this inquiry is often complicated by the fact that the law of the rendering forum is unclear or non-existent on the point in question. This difficulty is well illustrated in the case of Convention awards. The jurisdictional requirements of the Convention are set forth in article 25. See note 38 supra. However, the Convention's position on collateral attack of awards must be inferred from the articles and from the report of the Executive Directors. Article 53 of the Convention states that an award rendered by the centre is binding and enforceable against the parties to the dispute and article 54 explicitly requires enforcement of awards by contracting states. Moreover, article 54 appears to direct that enforcement is mandatory subject only to local rules of execution. This fact, when taken together with the articles dealing with modification of awards, see notes 52-54 supra, would seem to indicate that the Convention does not contemplate collateral attack on awards. There would be no problem with this position if the party resisting enforcement had appeared at the arbitral proceedings to contest the jurisdiction question. See Baldwin v. Iowa State Traveling Men's Ass'n, 283 U.S. 522 (1931). In the case of domestic judgments a failure to appear would result in a default judgment or at least in a judgment that would be subject to collateral attack. The Convention, however, provides that the absence of one of the partics will not prevent the Arbitral Tribunal from rendering an award that will be enforceable. See article 45 . Thus, a federal district court could be faced with the situation where the party resisting enforcement had not appeared at the arbitral proceedings and is seeking to contest the jurisdiction of the centre. Moreover, the power of the Convention to preclude collateral attack in such a situation, consistent with due process, is subject to some doubt. Thus, a federal district court would be constraiued to in. quire into the jurisdiction of the centre. It would also appear, however, that the court would be satisfied by the introduction of the consent agreement between the parties.

80 See article 41 .

${ }^{\circ 0}$ See note 52 supra and accompanying text.

1 See note 53 supra and accompanying text.

${ }^{\text {a2 }}$ See note 54 supra and accompanying text.
} 
seems to be found in article 53 , which states that " $[\mathrm{t}]$ he award shall be binding on the parties and shall not be subject . . . to any other remedy except those provided for in this Convention. . . ."; and in article 54, which requires that "[e]ach Contracting State shall recognize an award rendered pursuant to this Convention as binding...."

Rendition of an award under Convention procedures would not seem to raise either procedural or substantive due process objections under the United States Constitution. For example, since both parties are afforded notice ${ }^{93}$ and an opportunity to contest the jurisdiction issue, ${ }^{94}$ no unfairness is isolatable in the Convention's precluding collateral attack on awards. Moreover, precedent precludes a constitutional objection to jurisdiction based on consent. ${ }^{95}$ Finally, the substantive requirements of jurisdiction relating to the nature of the dispute and the identity of the parties are reasonably based.

Assuming that a Convention award will be entitled to recognition by a federal district court in accordance with full faith and credit principles and the terms of the Act, ${ }^{96}$ execution need not proceed in a summary fashion in all cases. It is true that execution of a Convention award against an American investor presents no problem, since enforcement will undoubtedly be sought in a jurisdiction in which assets of the investor are located. If, however, enforcement is sought in the United States against a state party, the investor may confront the defenses of sovereign immunity from jurisdiction ${ }^{97}$ and

DS The Convention Regulations provide for notification of an absent party to the effect that the Tribunal will proceed with arbitration; the absent party is then accorded a period of grace, not to exceed 60 days, in which to appear. INTERNATIONAI CoNvention for Settlement of Investment Disputes: Provisional Regulations and Rules, in 6 INT'L Legal Materials 225, 276 (1967).

oc The Convention provides that the Arbitral Tribunal shall be the judge of its own competence. See article 41. Moreover, this principle extends to questions of jurisdiction. Article $4 \mathrm{I}$ (2) provides: "Any objection by a party to the dispute that that dispute is not within the jurisdiction of the Centre, or for other reasons is not within the competence of the Tribunal, shall be considered by the Tribunal which shall determine whether to deal with it as a preliminary question or to join it to the merits of the dispute."

${ }^{\circ 5}$ See National Equip. Rental, Ltd. v. Szukhent, 375 U.S. 31I, 315-16 (1964).

00 See notes 107-16 infra and accompanying text.

${ }^{\circ}$ See, e.g., Victory Transp., Inc. v. Comisaria General, 336 F.2d 354, 358 (2d Cir. 1964), cert. denied, 381 U.S. 934 (1965); Chemical Natural Resources, Inc. v. Republic of Venezuela, $420 \mathrm{~Pa} .134,215$ A.2d 864, cert. denied, 385 U.S. 822 (1966). See generally Franck, The Courts, the State Department and National Policy: A Criterion for Judicial Abdication, 44 MINN. L. REv. 1101 (1960); note 27 supra. 
sovereign immunity from execution. ${ }^{98}$ A state party's invocation of the defense of sovereign immunity from jurisdiction arguably constitutes an implicit breach of obligations assumed under the Convention, since that agreement expressly requires that both the parties to a dispute ${ }^{90}$ and the contracting states ${ }^{100}$ recognize awards as binding and enforceable. Should the invocation of this defense constitute a breach, the way would be open for the investor's state to espouse his claim in international litigation. ${ }^{101}$

In contrast to the restricted nature of immunity from jurisdiction under the Convention, the defense of sovereign immunity from execution occupies a secure position, for article 53 provides that execution is to be governed by the law of the enforcing forum, and article 55 establishes that such law may include the execution immunity defense. ${ }^{102}$ Without specification, the clear inference is that a state party resisting enforcement may therefore raise the defense without breaching the Convention. For the investor seeking execution in federal district courts, this defense presents an insurmountable barrier. ${ }^{103}$ Ideally, state parties will comply with awards without the necessity of court proceedings. Should judicial enforcement be necessary, however, an American investor might be well advised to seek relief in jurisdictions having less strict execution immunity rules. ${ }^{104}$

Up to this point the discussion has focused on the positive steps which courts of the United States must take in enforcing Convention

${ }^{88}$ The doctrine of sovereign immunity from execution is firmly established in the United States. See note 28 supra. Indeed, there is authority for the view that immunity from execution cannot be waived. See Rich v. Naviera Vacuba, S.A., 295 F.2d 24 (4th Cir. 1961), discussed in R. Falk, The Role of Domestic Courts in the INTERNational Legal Order 139-70 (1964). See also Flota Maritima Browning de Cuba, S.A. v. Motor Vessel Ciudad de la Habana, 335 F.2d 619 (4th Cir. 1964) (dicta).

${ }^{\circ}$ Article 53; Report of the Executive Directors, supra note 59, at 530 .

${ }^{100}$ Article 54; Report of the Executive Directors, supra note 59, at 530 .

${ }^{101}$ Article 27 of the Convention permits a contracting state to pursue an international claim with respect to a dispute between one of its nationals and another contracting state if such other contracting state has failed to comply with the award rendered. But see notes 2-3 supra and accompanying text.

103 Article 55: "Nothing in Article 54 shall be construed as derogating from the law in force in any Contracting State relating to immunity of that State or any forcign State from execution."

${ }^{108}$ See Rich v. Naviera Vacuba, S.A., 295 F.2d 24 (4th Cir. 1961); Flota Maritima Browning de Cuba, S.A. v. Motor Vessel Ciudad de la Habana, 335 F.2d 619 (4th Cir. 1964) (dicta).

${ }^{10 s} \mathrm{~A}$ few countries permit execution against the property of a foreign sovereign in certain cases. See, e.g., Union of Soviet Socialist Republics v. Association France 
awards. There is also an interesting, and potentially important, question with respect to the obligation on American courts to accord recognition to the award by way of res judicata or collateral estoppel. ${ }^{105}$ The application of these doctrines in Convention award enforcement is not affected by precedents relating to recognition of arbitral awards arising under state law, since the effect to be accorded the international awards presents a federal question under the Convention on the Settlement of Investment Disputes Act. ${ }^{106}$ Federal law seems clearly to entitle an arbitration award-particularly an award upon which a judgment has been obtained-to both res judicata and collateral estoppel effect. For example, in Panza v. Armco Steel Corporation, ${ }^{107}$ the District Court for the Western District of Pennsylvania asserted that "[a]n arbitration award, unless and until invalidated, creates or authoritatively declares rights even as a judgment does."108 In Oinoussian Steamship Corporation of Panama v. Sabre Shipping Corporation ${ }^{\mathbf{1 0 9}}$ a district court, directly ruling on the res judicata and collateral estoppel issue, held that an arbitration award within the scope of the agreement submitting the dispute to arbitration is conclusive as to fact issues and

Export, 56 Journal du Droit International (Clunet) 1042 (1929) (French court); Socobelge v. 1'Etat Hellenique, 79 Journal du Droit International (Clunet) 244 (1952) (Belgian district court). See generally W. Bishop, InTERnational LAw 580-81 (2d ed. 1962).

${ }^{205}$ Res judicata refers to the effect to be given to a prior proceeding in barring a subsequent cause of action on the same subject matter, while collateral estoppel is concerned with the effect to be accorded in subsequent litigation to the determination of specific issues in a prior proceeding. See Developments in the Law-Res Judicata, 65 HARV. L. REV. 818 (1952).

${ }^{100}$ The Convention on the Settlement of Investment Disputes Act, 22 U.S.C. $\$ \$ 1650$ 1650a (Supp. II, 1965-66), makes the enforcement of Convention awards a federal question to be determined in federal courts. Arguably, therefore, all issues with respect to the effect of Convention awards present a question of federal law. In addition, while the Federal Arbitration Act, 9 U.S.C. $\$ \S 1-14$ (1964), does not address itself directly to enforcement of arbitration awards, it forms the basis for the federal rule concerning the conclusive effect to be given arbitration awards. See notes 107-113 infra and accompanying text. The recent decision by the United States Supreme Court in Prima Paint Corp. v. Flood \& Conklin Mfg. Co., 388 U.S. 395 (1967), seems to indicate that the Federal Arbitration Act will govern arbitration agreements in interstate commerce in both federal and state courts.

107208 F. Supp. 50 (W.D. Pa. 1962), aff'd, 316 F.2d 69 (3d Cir.), cert. denied, 375 U.S. 897 (1963).

${ }^{208} I d$. at 54 .

${ }^{200} 224$ F. Supp. 807 (S.D.N.Y. 1963). See also Amicizia Societa Navegazione v. Chilean Nitrate \&: Iodine Sales Corp., 274 F.2d 805 (2d Cir.), cert. denied, 363 U.S. 843 (1960). 
interpretations of law.110 In according res judicata and collateral estoppel results to arbitration awards, the federal courts seem to reason that the policy of avoiding litigation embodied in arbitration should outweigh strict adherence to the doctrines' technical requirements. Thus, the judiciary has not been troubled that the traditional collateral estoppel requirement of actual litigation is not precisely met in an arbitration proceeding. ${ }^{111}$

In further implementation of the policy of limiting litigation, federal courts have held that an award will be deemed valid and entitled to conclusive effect, unless a party has availed himself of the modification provisions of the Federal Arbitration Act.12 Although Convention awards could have been deemed within the coverage of the Federal Arbitration Act as arbitrations of disputes in foreign commerce, ${ }^{113}$ application of the modification provisions of that Act is expressly precluded by the subsequent Convention on the Settlement of Investment Disputes Act. ${ }^{114}$ Instead, the Convention specifies its own procedures for award alteration. ${ }^{115}$ But this fact should not bring about a result different from the prevailing federal rule on the conclusiveness of arbitration decrees, since the policy of minimizing litigation by permitting only extrajudicial modification remains viable irrespective of the source of possible alteration. ${ }^{110}$

\section{ConcLuston}

A thorough consideration of the operation of the Convention demonstrates that its attempts to institutionalize international arbitration, and particularly enforcement of awards, are, in practical

${ }^{110} 224$ F. Supp. at 809.

${ }^{111}$ See, e.g., Cromwell v. Sac, 94 U.S. 351 (1876); Buromin Co. v. National Aluminate Corp., 70 F. Supp. 214 (D. Del. 1947). See generally Developments in the Law-Res Judicata, 65 HARv. L. REv. 818, 840-41 (1952).

${ }^{212}$ See notes 107 \& 109 supra and accompanying text. See also Federal Arbitration Act $\$ \S 9-11,9$ U.S.C. $\$ \S 9-11$ (1964).

${ }^{213}$ See note 106 supra.

${ }^{214}$ See note 74 supra.

${ }^{215}$ See notes 52-54 supra.

${ }^{110}$ Since the World Bank Convention provides avenues for modification of awards, due regard for the policies of arbitration should result in the according of conclusive effect to awards of the centre. Indeed, the Convention itself appears to contemplate such a result. Article 26 of the Convention states that consent to arbitration shall be deemed to designate arbitration as an exclusive remedy. See note 48 sutpra and accompanying text. Although the parties may agree to exhaust local remedics before proceeding to arbitration, once an arbitral award has been rendered, article 26 precludes resort to any other mode of redress. See Report of the Executive Directors, supra note 59, at 528-29. 
terms, very modest. The incorporation of local rules of execution by articles 54 and $55^{117}$ renders enforcement impossible against a state to which the sovereign immunity defense is available. Indeed, in American courts it is reasonable to assume that the Convention on the Settlement of Investment Disputes Act will be used primarily by state parties to enforce awards against American investors, since the sovereign immunity defense will be available to state parties. ${ }^{118}$ To correct the disparity of treatment between investors and state parties, the courts and the United States State Department should give consideration to modification of domestic rules. ${ }^{119}$ In light of this country's restrictive approach to submitting disputes to the centre, ${ }^{120}$ the Convention will not likely have a measurable effect on levels of foreign investment in the United States. Further, weaknesses in the enforcement procedures as against a state party may prevent the legal aspects of the Convention from serving as a major stimulus to increased foreign investment in underdeveloped states. However, it may be that substantive rights conferred by the Convention are not the key to its effectiveness as a means for encouraging foreign investment. Not only might the publicity afforded by an international forum produce voluntary compliance with awards but also acceptance

\footnotetext{
${ }^{117}$ See notes 51 \& 98 supra and accompanying text.

218 See note 102 supra.

${ }^{110}$ The present trend in the area of sovereign immunity is clearly away from the old absolute principles toward a more flexible approach. The Tate Letter, 26 STATE DEPT. BuLl. 984 (1952), is evidence of this trend in the area of immunity from jurisdiction. Sovereign immunity from execution has not yet been affected by this process of erosion. See notes 28 \& 98 supra and accompanying text. In a critical discussion of the sovereign immunity from execution doctrine, one leading commentator has stated that: "The same equity considerations that led the Supreme Court in Republic of China to allow a counterclaim against a sovereign plaintiff should also allow enforcement against a sovereign defendant that has consented, or has been found subject, to prosecutions. Immunity, as a modern concept, should be correlated with functions, not with status." Falk, supra note 98, at 166; cf. National City Bank v. Republic of China, 348 U.S. 356 (1955). Enforcement of Convention awards would seem to offer an attractive area in which to modify the existing practice in the United States with respect to sovereign immunity from execution. Article 53 of the Convention requires the parties to a dispute to recognize the award as binding, and while article 55 states that the Convention does not attempt to change the rules concerning sovereign immunity from execution, it is equally clear that enforcement of Convention awards is to be governed by the execution rules of the forum. Thus, there is no reason stemming from the provisions of the Convention which would militate against modification of sovereign immunity from execution. Moreover, Convention awards would not seem to impinge on the sensitive areas of diplomacy and military operations where the justification for the immunity from execution defense is most persuasive.

${ }^{120}$ See notes 68-71 supra and accompanying text.
} 
of the Convention, as a reflection of a friendly attitude toward foreign investment, may enhance the ratifier's position as a potential recipient of international capital. Thus, the success of the Convention may ultimately depend, not on the effectiveness of its enforcement procedures, but on the infrequency with which parties resort to them. 